WIDER Working Paper 2017/170

\title{
Backsliding and reversal
}

The J-Curve revisited

Rachael Calleja, David Carment, Mark Haichin, and Peter Tikuisis*

September 2017 
Abstract: Ian Bremmer published a treatise on the stability of states built on the notion that states fall along a curve resembling a slanted "J" when plotting their stability against openness. States in the turnover process are considered unstable, and are at risk of either reversing to a closed and stable system or even collapsing. Our paper shifts the J curve's associated conditions to a model to more accurately specify the causes of reversal in which crises of instability and backsliding occur. We define stability as a function of two state dimensions: authority and capacity, and apply the remaining state dimension of legitimacy as a proxy for openness. We find that transitions can reverse, oscillate, or simply stall, which are exemplified in the different types of states we categorize. The paper concludes with implications for policy and the application of the model to conflict prediction.

Keywords: C52, C55

JEL classification: democracy, backsliding, fragile states, instability, hybrid states, forecasting

Tables and figures: all authors' own work based on data provided by CIFP (Country Indicators for Foreign Policy).

Acknowledgements: The authors would like to acknowledge the support of the Social Sciences and Humanities Research Council and the United Nations University World Institute for Development Economics Research UNU-WIDER, and thank Rachel Gisselquist for comments on earlier drafts.

*All authors: Norman Paterson School of International Affairs, Carleton University, Ottawa, Canada. Corresponding author David Carment, david_carment@carleton.ca.

This study has been prepared within the UNU-WIDER Visiting Scholar programme.

Copyright (C) The Authors 2017

Information and requests: publications@wider.unu.edu

ISSN 1798-7237 ISBN 978-92-9256-396-7 https://doi.org/10.35188/UNU-WIDER/2017/396-7

The United Nations University World Institute for Development Economics Research provides economic analysis and policy advice with the aim of promoting sustainable and equitable development. The Institute began operations in 1985 in Helsinki, Finland, as the first research and training centre of the United Nations University. Today it is a unique blend of think tank, research institute, and UN agency — providing a range of services from policy advice to governments as well as freely available original research.

The Institute is funded through income from an endowment fund with additional contributions to its work programme from Denmark, Finland, Sweden, and the United Kingdom.

Katajanokanlaituri 6 B, 00160 Helsinki, Finland

The views expressed in this paper are those of the author(s), and do not necessarily reflect the views of the Institute or the United Nations University, nor the programme/project donors. 
Just over ten years ago, Ian Bremmer published a treatise (2006) on the stability of states built on the notion that states fall along a curve resembling a slanted ' $\mathrm{J}$ ' when plotting their stability against openness. The basic idea is that states to the right of the turnover (bottom of the curve) are increasingly open while those to the left are increasingly closed. As states transition from the left side of the curve to the right, they become more open to interactions with the rest of the world (e.g., free press), as well as in their own domestic politics (e.g., free elections). In doing so, they are expected to gradually replace the authoritarian elites of the old system with more democratic political institutions. However, states in the turnover process are considered unstable, and are at risk of either reversing to a closed and stable system or even collapsing. States on either side of the turnover exhibit increased stability the further they rise along the curve, with the implicit assumption that closed states cannot reach the same level of stability as the most open states.

While stability is attained with strong authority and capacity, openness elevates the potential for a state to achieve higher stability than a closed state. The continued prevalence of partially liberalized regimes begs the question why such regimes have not transitioned out of hybridity (i.e., towards full liberalization or consolidated democracy).

States that reside near the turnover are considered in crisis, lacking the authority and capacity to prevent and withstand destabilizing shocks. Crises arise when leaders confront strategic tradeoffs. On the one hand, leaders have to establish a power base that is broad and inclusive enough to fend off potential challengers. On the other hand, to maintain support from within their narrow political base, leaders have to show they are unwilling to compromise on fundamental policy issues, which can result in increased instability if the narrower political base prevails and generates narrow benefits for themselves. Institutional changes create opportunities for organized political groups to more openly pursue their objectives in the political arena along narrow bands of political support. In a nutshell, crises of destabilization begin when leaders take advantage of uncertainty in the political system to consolidate their power base and to provide benefits primarily to their political supporters.

According to Bueno de Mesquita et al. (2003), and Bueno de Mesquita and Smith (2012), the nature of the benefits for the political base will vary with the nature of the government. Democratic regimes need to reward their base with public goods that benefit large parts of the population, as even a narrow political base in such a regime will be too large to win over with private benefits. Autocratic regimes, on the other hand, are able to survive with a smaller support base, and can therefore use private benefits to tie their welfare to that of the current regime. A government that lacks sufficient resources to retain either of these supporters is likely to lose their power base, thus becoming vulnerable to challenges that could destabilize it.

A similar theory regarding the transition between autocratic and democratic regimes, albeit focusing on the role of state administrative capacity, is that proposed by Bäck and Hadenius (2008). When plotting levels of democratization against state administrative capacity, states on the left and right side of a J curve demonstrate high levels of capacity. Those at the bottom of the curve, which are presumed to be transitioning from authoritarianism to democracy, have lower levels of capacity. The explanation for this trend in the model is that authoritarian states require a strong repressive apparatus for the regime to retain power, and that the democratization process initially erodes this process. As the state democratizes further (moving further upwards on the right of the curve), the emergence of democratic institutions and increasing political participation increases the state's administrative capacity once again, potentially beyond what those on the left could achieve. 
In brief, what emerges from Bremmer's J curve, and similarly with the above two hypotheses of regime change, is a dichotomous ranking of countries susceptible to crises of instability. Countries with highly functional democratic processes are more stable, but then so too are deeply entrenched repressive regimes. The most unstable countries are those with moderate levels of democratic performance. These partially liberalized regimes 'are neither clearly democratic nor conventionally 'authoritarian' (Diamond, 2002). A myriad of labels has been used to describe these gray zone regimes, including 'hybrid' (Diamond, 2002; Wigell, 2008), 'semi-democracies' (Diamond et al., 1989), 'illiberal democracies' (Zakaria, 1997), 'electoral democracies' (Diamond, 1999), 'competitive authoritarian' (Levitsky and Way, 2002), 'semi-authoritarian' (Ottaway, 2003), 'soft authoritarianism' (Means, 1996), 'electoral authoritarianism' (Schedler, 2006; 2009) and 'anocracies' (Marshall and Cole, 2014).

At face value, Bremmer's key point about hybrid regimes being susceptible to instability and reversal appears valid. For example, according to the 2016 report by Freedom House, 59 out of 195 countries are currently considered 'partly free' (Freedom House, 2016). Despite moving out of authoritarianism through the adoption of varying degrees of political, social, and economic liberalization, these are countries that have not fully transitioned to democracy or have reversed in some key areas as they began to open up. Such regimes, notably found across Africa (e.g., Kenya, Mozambique, Zambia), post-communist Eurasia (e.g., Albania, Ukraine), Latin America (e.g., Haiti, Mexico), and Asia (e.g., Malaysia, Indonesia, Pakistan), began transitioning with the 'third wave' of democratization (initiated in 1974) and were expected to transform into full democracies. However, many remain 'partially liberalized' having only adopted varying degrees of democratization (see Vanhanen, 2000).

However, we believe Bremmer's interpretation of the kinds of states that are susceptible to instability and reversal is too simplistic, neglecting key interactions between the state dimensions of legitimacy, capacity, and authority that are not part of Bremmer's framework. The key point missed by Bremmer is that there are multiple hybrid regimes that failed to make the full transition to democracy or autocracy. The state dimensions of legitimacy, capacity, and authority were used by Tikuisis and Carment (2017), and Tikuisis, Carment, Samy, and Landry (2015) to categorize six types of states beyond simply ranking them from strength to weakness, with hybrid regimes occupying the middle ground. In this paper, we formulate an expression of stability against openness involving the above three dimensions that places states along a modified $\mathrm{J}$ curve with greater discrimination.

The benefits of our approach are two-fold. First, we shift from Bremmer's framework of associated conditions to a causal model. Second, we more accurately specify the causes of reversal in which crises of instability occur. To meet those objectives, we identify states according to the six types characterized by Tikuisis and Carment (2017). We then define stability as a function of two state dimensions: authority and capacity, and apply the remaining state dimension of legitimacy as a proxy for openness.

In testing the model, we find that shifts to openness and reversals leading to increasing instability are not as clear cut as Bremmer argues. Transitions can reverse, oscillate, or simply stall, which are exemplified in the different types of states we categorize. For example, we find that the least stable states experience the highest volatility in shifts between stability and openness, while the most stable states exhibit the lowest volatility. Improved capacity was solely responsible for the significantly improved stability of all state types while changes in openness (essentially legitimacy) were mixed over the 1996-2015 period of study. 
In the following sections, we first elaborate on the causal mechanisms that generate instability and relate these findings specifically to hypothetical claims regarding expected outcomes. We then present a causal model and test it using our six-fold typology of states followed by a section on policy implications. Our construct of stability also allows us to develop a novel risk index of destabilizing intrastate damage based on a conflict risk index, which in our view ignores state capacity to deal with conflict. Finally, we conclude with a summation and directions for future research.

\section{Causes of Instability and Reversal}

In reviewing our reassessment of the J curve, it's important to note that research examining the conditions that tend to favour the emergence of stable open societies has yielded several competing results. Lipset's (1959) seminal contribution on modernization theory argued that economic development is positively correlated with democracy. Lipset's view was that industrialization, urbanization, wealth, and education would provide the conditions, rather than the causes, for democracy to flourish. While the relationship identified by Lipset has been extensively studied, the modernization perspective can be considered deterministic, where democratization becomes a byproduct of development rather than an outcome of deliberate action (Przeworski and Limongi, 1997).

The literature on democratic consolidation suggests that democratic transitions could be impeded by rapid growth (Lipset, 1959; Olson, 1993), high rates of inflation (Hirschman, 1986), extreme income inequality, inadequate constraints on executive power, ethnic fragmentation, and the insufficient provision of 'public goods' (Kapstein and Converse, 2008).

In our view, the plausibility of Bremmer's argument regarding increasing/decreasing stability hinges on claims regarding interactions between the superordinate elements of state authority, capacity, and legitimacy and not just economic development and democracy. For example, positive changes in authority that address societal well-being not only provide valuable guidance for government policy, they also reduce literal barriers to commerce and economic development (measures of capacity) such as restrictions on citizen movement and assembly (measures of legitimacy). Responsiveness may also induce governments to produce policies addressing popular concerns that are not growth-focused, such as wealth distribution and social programming, and which by extension increase state legitimacy.

Goldstone (2008) shows that state stability is related to state effectiveness (i.e., how well a state carries out basic functions such as providing security, promoting economic growth, law making, and delivering services) and legitimacy (i.e., the degree to which state actions are considered 'reasonable' based on domestic social norms). For Goldstone, states with both effectiveness and legitimacy are typically stable, while states that possess one or the other may be prone to failure. Of particular interest to discussions of partially liberalized regimes for instance, Goldstone suggests that while newly emerging democracies tend to have some legitimacy (although, this can also be eroded in cases with severe corruption), they might be ineffective and unable to provide economic and physical security to the populous. In these cases, 'democracies that are perceived as ineffective are often replaced by military regimes in coups' (p. 291). The result is democratic collapse similar to that seen in Nigeria in 1983 (Goldstone, 2008).

For Olcott and Ottaway (1999), both state capacity and political leadership are particularly significant determinants of stability in semi-authoritarian regimes. Differentiating between regimes in 'equilibrium', 'decay', and 'dynamic change', Olcott and Ottaway examine how capacity and leadership influence the direction and potential transformation of partially liberalized regimes. For instance, while countries in 'equilibrium' tend to be those that have brought about growth and 
established legitimate leaders (e.g., Egypt before the Arab Spring), 'decay' is likely to follow countries with poor capacity to influence development while 'dynamic change' in the pursuit of further liberalization is often driven by political leaders seeking to promote further growth, trade, and integration into the international system (e.g., China).

In combining these insights on the relationship between authority, capacity, and legitimacy, we see that there are three scenarios where instability or its potential can ensue. First, the potential for instability occurs in countries where weak legitimacy is the key driver. According to Takeuchi et al. (2011) whose insights are similar to Goldstone's, these are countries that have demonstrated a high capacity to provide security and services to the population but suffer from weak legitimacy due to expanding inequalities under authoritarian management. In this weak legitimacy scenario, the state-building experience generally does not improve the state's ability to provide security and social services, resulting in a failure to strengthen legitimacy. The risk that such states face is a closure of the political system (i.e., diminished liberalization/openness) even when growth is achieved. This leads to the left upswing of Bremmer's J Curve when a state with good capacity fails to establish strong legitimacy.

A second scenario is one where the country fails to develop effective capacity. The relationship between state stability and economic development is well established throughout the literature (see Przeworski and Limongi, 1997; Przeworski et al., 2000). According to Przeworski and Limongi, economic development is important for the sustainability of democratic regimes, where partially liberalized regimes unable to enhance capacity tend to be more fragile and unstable than countries with higher levels of economic growth. Leaders of 'Impoverished' states may simply not have the (natural) resources to grow their capacity. The rationale for capacity driven instability is that populations are unlikely to commit to open political systems and democratic consolidation if they do not see tangible improvements in local conditions, thus contributing to potential unrest and instability. To avoid this under conditions of economic liberalization, governments promote linkages with different economic groups to avoid becoming beholden to any particular faction. Politically, Brumberg suggests that providing social groups with a degree of freedom allows states to pursue a 'divide and rule' strategy whereby control is maintained by playing groups against each other. In such cases, partial economic liberalization can be seen as a strategy not for democratization, but to sustain authoritarian control.

A third scenario describes authority-driven instability in a fragile state where countries transitioning to democracy 'backslide' from openness to regime failure and civil war, as was the case in Côte d'Ivoire (2002) and Guinea (2001) (Marshall and Cole, 2014). Weak or nascent democracies backslide when they become less democratic (the Eastern European model), when their democratic practices are subverted and replaced by military usurpers (the Latin American and sometime African models), or when they fail to consolidate opportunities to grow as democratic polities and revert to autocracy (the Middle Eastern model).

For example, Huntington (1993) warns that previous waves of democratization have been followed by 'reverse waves' that pull countries away from newfound democracy. Driven by weak democratic values among elite and society, economic setbacks, social and political polarization, the breakdown of law and order due to insurgency and reverse 'snowballing', such reverse transitions could steer countries into the 'gray zone' between democracy and authoritarianism. While Huntington's wave approach has received a mixed reception generating both support (Strand, Hegre, Gates, and Dahl, 2012) and rejection (Doorenspleet, 2005; Przeworski, Alvarez, Cheibub, and Limongi, 1996), Diamond (2015) contends that instead of a reverse wave, the last decades have seen a 'protracted democratic recession' that has ebbed freedoms in some regions, but has not reversed democracy as Huntington predicted. 
In reference to Bremmer's J Curve, there is some debate about where to place hybrid states along the bottom of the curve, considering that not all researchers consider hybrid regimes transitional (Ottaway, 2003) in so far as they are deliberately designed to 'maintain the appearance of democracy without exposing themselves to the political risks that free competition entails' (p. 3). Indeed, there are many examples of countries that have remained stable in their hybridity. For instance, some observers have pointed to pre-Arab Spring Egypt as a hybrid country with stability that 'can be sustained indefinitely, if there is astute political leadership and if the resources exist to keep public demands at bay' (Menocal et al., 2008 p. 32). Similarly, Brumberg (2005) notes that the adoption of hybrid models that utilize liberalized economies and pluralistic political systems may actually help Arab states maintain control.

In contrast, Menocal et al. (2008) find that hybrid regimes tend to be unstable, unpredictable, or both. Indeed, Marshall and Cole (2014) state that hybrid regimes 'very often reflect inherent qualities of instability or ineffectiveness and are especially vulnerable to the onset of new political instability events such as outbreaks of armed conflict, unexpected changes in leadership, or adverse regime changes' (p. 21). Menocal et al. continue to suggest that such instability is caused by the absence of a 'principled' commitment to the rules of democracy by elites and the public. For instance, in examining public opinion data from various countries in Africa, Bratton et al. (2007) find that while people are attached to the 'idea' of democracy, they have little knowledge of its specific institutional components.

In essence, processes of reversal and instability are more complex than those implied in Bremmer's $\mathrm{J}$ Curve. While it is clear there are numerous examples of states that stall or even reverse in their quest for democratization, the underlying reasons need to be more carefully understood. We believe that reversals can occur when states achieve sufficient capacity to meet the needs of their population, yet are caught in a legitimacy trap with little inclination to exit. Then there are those states that are perpetually economically weak and often plagued by violence, perhaps shifting slightly with changes in effectiveness and leadership, but not sufficiently enough to escape fragility. Such conditions can be exacerbated by high economic inequality (Acemoglu and Robinson 2001; Houle 2009) or low development and recessions (Svolik 2008). Finally, there are those states with strong authority and democratic aspirations, but without sufficient capacity to break free of instability. All of these states, including stable ones, can be located in unique clusters along a 'fattened' J curve using the state dimensions of authority, legitimacy, and capacity introduced earlier. We demonstrate these points in the following section.

\section{$3 \quad$ Methodology}

The three dimensions of stateness of authority (A), capacity (C), and legitimacy (L) were first proposed by Carment et al. (2006) to arrive at a fragility index (FI). State authority reflects the institutional ability of government to enact binding legislation over its population and provide it with a stable and secure environment. State legitimacy reflects leadership support of the population along with international recognition of that support. State capacity reflects the state's resources that can be mobilized for developmental and defensive purposes. All state dimensions are scaled from 1 to 9 representing strong to poor performance, and FI is a simple average of the three.

Tikuisis et al. (2015) and Tikuisis and Carment (2017) introduced a state categorization schema to describe six types of states based on the values of A, L, and C, as follows. Fragile states are those considered to perform poorly in all three state dimensions with a resultant high value of FI (essentially within the high tertiary of values). Brittle states are those that perform well in A and C (mostly mid tertiary values), but score poorly in L (essentially sufficiently resourced, but autocratic). 
Impoverished states perform moderately well in A and L (mostly mid tertiary values), but are challenged by poor capacity (essentially sufficiently managed, but poor). Remaining states are categorized as struggling functional, moderately functional, or highly functional according to their FI value (essentially a separation by degree of performance in all three dimensions of state with FI values in the low and mid tertiary range). Hypotheses regarding these different state types are:

H1: Fragile states are expected to occupy the portion below the turnover of the J curve given that they are the most unstable states.

H2: Brittle states are expected to occupy the upper portion on the left side of the J curve given that they are ostensibly stable with restricted openness.

H3: Impoverished states are expected to occupy the lower portion on the right side of the J curve given that they tend towards openness, yet are susceptible to instability due to poor capacity.

H4: Struggling functional states are expected to mostly occupy the portion of the $J$ curve above the impoverished states (i.e., increased stability) given their stronger capacity.

H5: Moderately functional states are expected to occupy the right side of the J curve above the struggling functional states given that all three dimensions of stateness are stronger.

H6: Highly functional states are expected to occupy the right side of the J curve above the moderately functional states given that all three dimensions of stateness are the strongest.

To generate a likeness of the J curve, we quantify a state's stability and openness using the state dimensions of A, L, and C. Borrowing on the concept of Bremmer, state stability essentially comprises authority and capacity, and is herein quantified as $9-(\mathrm{A}+\mathrm{C}) / 2$. We assume that state openness can be represented by legitimacy and quantified as $9-\mathrm{L}$.

Following the methodology of Tikuisis and Carment (2017), authority and legitimacy values were obtained from the World Governance Indicators using World Bank data, and capacity was based on GDP data using the same source. To maximize the number of states for analysis ( $n=172$ ), the period of study spanned from 1996 through 2015, inclusive, although data were not available for odd years until 2003. Further, data were incomplete for 1996 and $1998(\mathrm{n}=167), 2000(\mathrm{n}=170)$, 2012 and 2013 ( $\mathrm{n}=170), 2014(\mathrm{n}=168)$, and $2015(\mathrm{n}=164)$. Results are based on the data available without imputation.

\section{$4 \quad$ Results}

Figure 1 shows the scatter plot of stability against openness for all states identified by type using the state's average values of A, C, and L during the period from 1996 and 2015 inclusive. Although not a thin curve, it is apparent that the states fall within the outline of a broad ' $\mathrm{J}$ ' with several notable features that were hypothesized. Highly and moderately functional states reside in the upper right of the distribution with relatively high stability and openness, supporting both $\mathrm{H} 5$ and H6. Struggling functional states mostly reside to the right of the turnover (located approximately at an openness value of 2.2) with relatively less stability and openness, supporting H4, though some remain on the left of the turnover. Fragile states mostly reside at the bottom and to the left of the turnover with very low stability and openness, supporting H1. Impoverished states reside to the right of the turnover with low stability and moderate openness, supporting H3. And finally, brittle states mostly reside to the left of the turnover with moderate stability, but low openness, partially supporting $\mathrm{H} 2$ as several brittle states share similar values of stability and openness with some struggling functional states. This depiction also confirms that states to the left of the turnover do not attain the elevated stability of states with high openness (i.e., highly and moderately functional states). 
Figure 1. Scatter plot of stability vs openness for 172 states

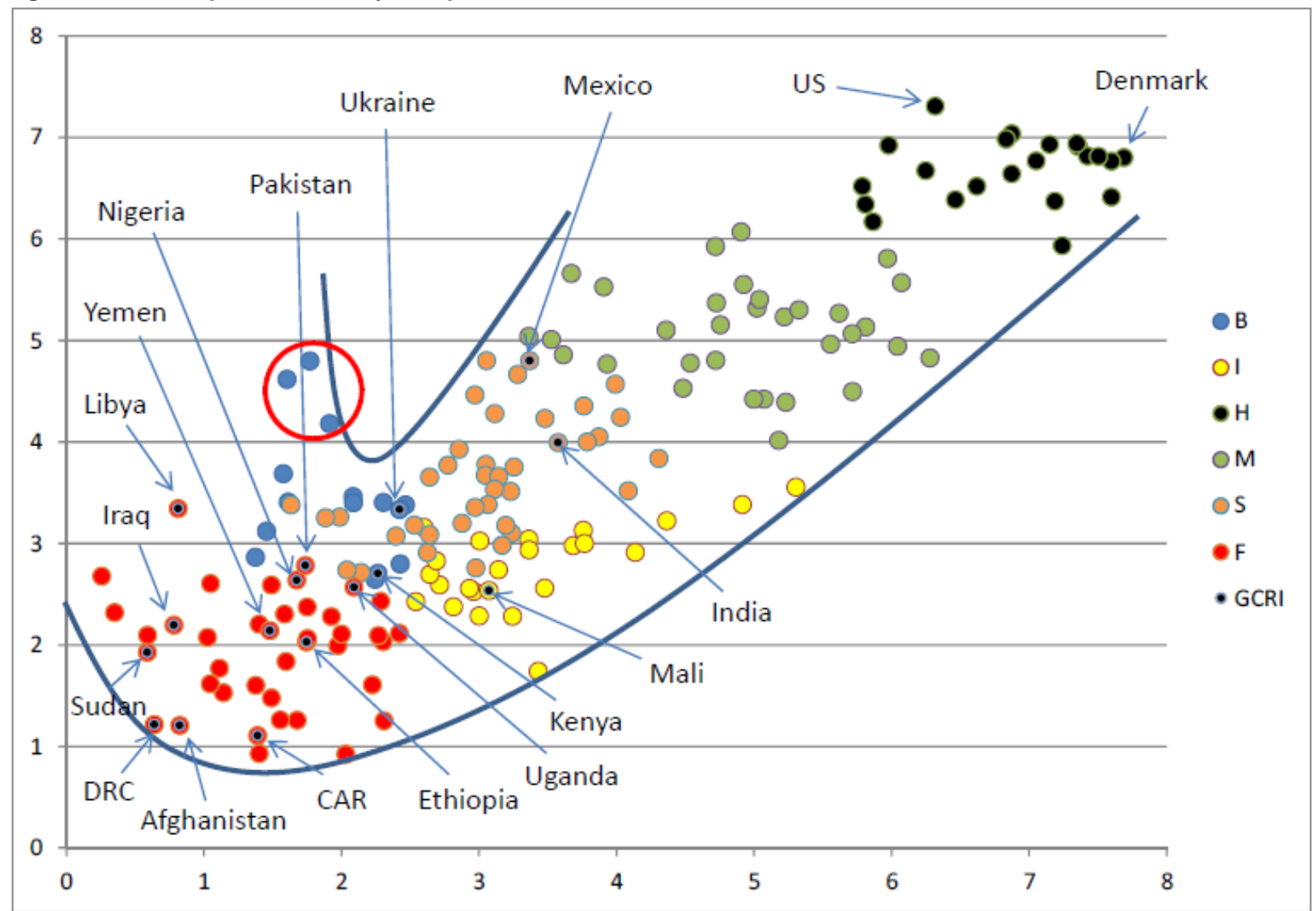

Note: colour-coded by cluster type $(\mathrm{B}=$ brittle, $\mathrm{I}=$ impoverished, $\mathrm{H}=$ highly functional, $\mathrm{M}=$ moderately functional, $\mathrm{S}=$ struggling functional, and $\mathrm{F}=$ fragile).

States within the circle clockwise from the top are Saudi Arabia, Russia, and China. The 16 states labelled as GCRI (Global Conflict Risk Index) are among the top 20 predicted at risk of violent internal conflict.

Bremmer identified authoritarian regimes as those that reside on the upper left of the J-curve. Our analysis allows for greater discrimination given that capacities can vary widely among states that are closed, or at least less open. For example, Saudi Arabia, Russia, and China (all categorized as brittle) display the highest stability among closed states and are largely responsible for the upswing of the J-curve (openness ranging from 1.6 to 1.9; stability ranging from 4.2 to 4.8; see Figure 1). Less capable authoritative and semi-authoritative states such as Afghanistan, Central African Republic, and the Democratic Republic of Congo (all categorized as fragile), meanwhile, display very low stability among even less open states (openness ranging from 0.6 to 2.0; stability ranging from 0.9 to 1.2). Overall, the diversity in both stability and openness among states within their clusters causes a 'fattening' of the distribution of states.

Inspection of the average of all the states' stability values indicates an overall upward shift in stability (3.6 to 4.0) between 1996 and 2015, which is due to an improvement in capacity (5.8 to 5.2) without any significant change in authority (5.0 to 4.9). There was also no significant change in openness ( 3.5), indicating no overall change in state legitimacy (5.5 to 5.5). However, changes within the clusters varied, as seen in Figure 2 and detailed in Table 1. For example, stability is seen to increase significantly while openness worsened for the averages of both highly and moderately functional states. In contrast, both stability and openness significantly improved for struggling functional states. For the remaining three clusters (B, I, and F), stability improved while openness deteriorated only for B states, although openness also deteriorated for I and F states near the 
midpoint followed by a reversal with no significant net change. Figure 3 illustrates the chronological changes for $\mathrm{F}$ states.

Figure 2: Average cluster values of stability vs openness for the years 1996, 2006, and 2015

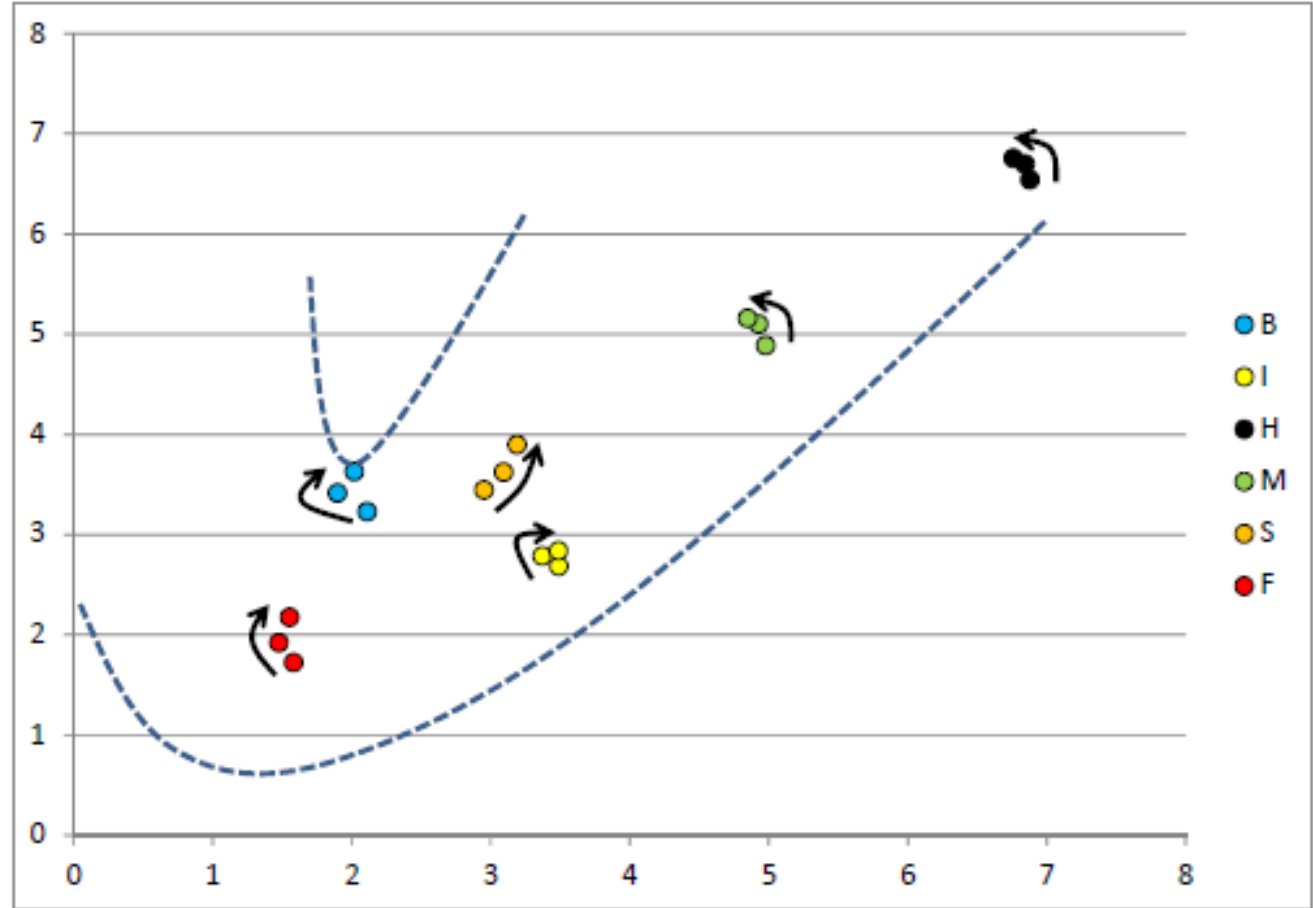

Notes: shown in chronologic order by the arrows. $(B=$ brittle, $I=$ impoverished, $H=$ highly functional, $M=$ moderately functional, $\mathrm{S}=$ struggling functional, and $\mathrm{F}=$ fragile)

Figure 3. Chronology of stability vs openness for F states

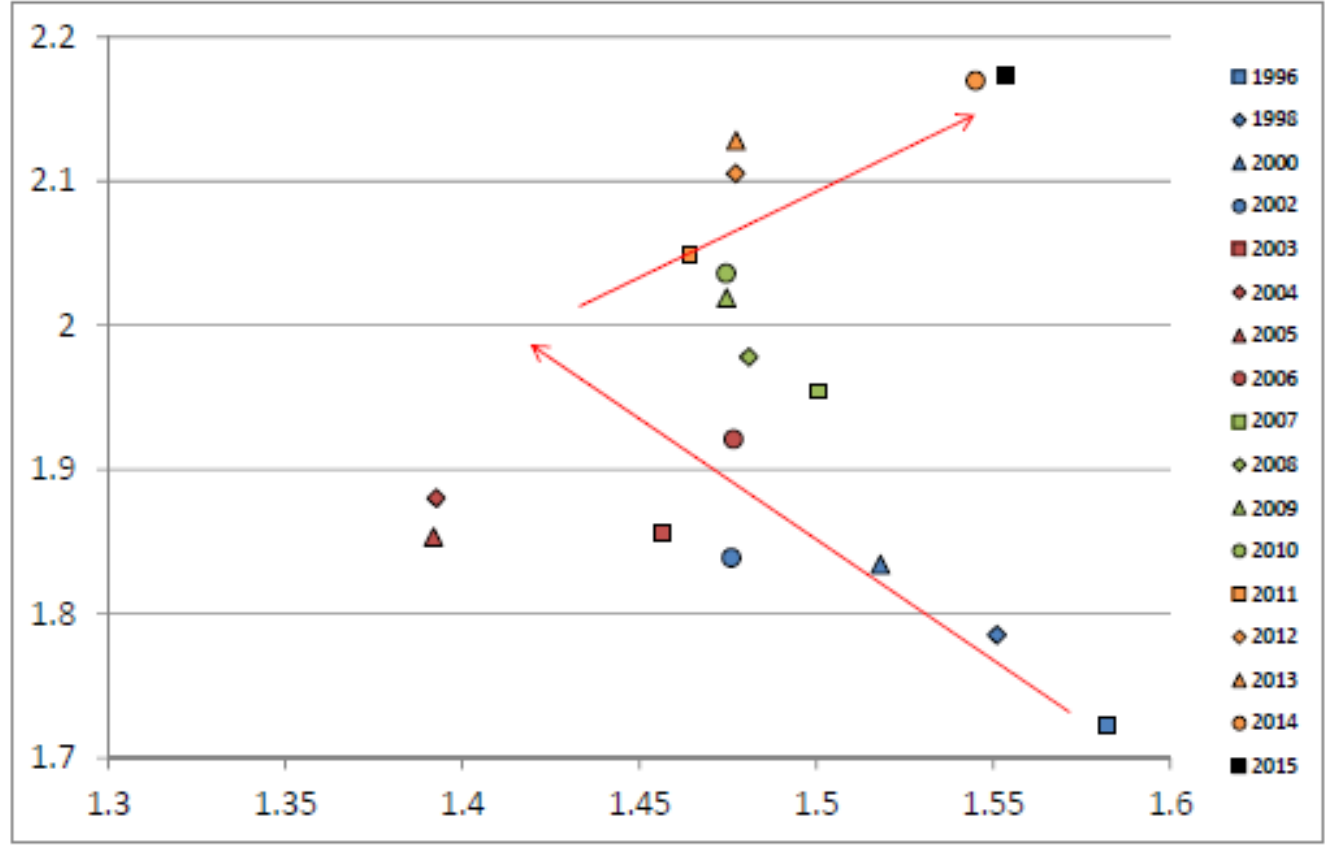

Note: arrows shown for emphasis. 
Table 1. Significance of changes for clusters and selected states between 1996 and 2015

\begin{tabular}{|l|l|l|l|}
\hline State(s) & S vs O & S vs Yr & O vs Yr \\
\hline B (15) & $\mathrm{p}<0.01 ;-v e$ & $\mathrm{p}<0.01 ;+\mathrm{ve}$ & $\mathrm{p}=0.01 ;-\mathrm{ve}$ \\
\hline $\mathrm{I}(24)$ & $\mathrm{ns}$ & $\mathrm{p}<0.01 ;+\mathrm{ve}$ & $\mathrm{ns}$ \\
\hline $\mathrm{H}(22)$ & $\mathrm{ns}$ & $\mathrm{p}<0.01 ;+\mathrm{ve}$ & $\mathrm{p}=0.01 ;-\mathrm{ve}$ \\
\hline $\mathrm{M}(32)$ & $\mathrm{p}<0.01 ;-\mathrm{ve}$ & $\mathrm{p}<0.01 ;+\mathrm{ve}$ & $\mathrm{p}<0.01 ;-\mathrm{ve}$ \\
\hline $\mathrm{S}(39)$ & $\mathrm{p}=0.01 ;+\mathrm{ve}$ & $\mathrm{p}<0.01 ;+\mathrm{ve}$ & $\mathrm{p}<0.01 ;+\mathrm{ve}$ \\
\hline $\mathrm{F}(40)$ & $\mathrm{ns}$ & $\mathrm{p}<0.01 ;+\mathrm{ve}$ & $\mathrm{ns}$ \\
\hline Afghanistan & $\mathrm{p}=0.04 ;+\mathrm{ve}$ & $\mathrm{p}<0.01 ;+\mathrm{ve}$ & $\mathrm{ns}$ \\
\hline Belarus & $\mathrm{ns}$ & $\mathrm{p}<0.01 ;+\mathrm{ve}$ & $\mathrm{ns}$ \\
\hline Brazil & $\mathrm{ns}$ & $\mathrm{ns}$ & $\mathrm{ps}$ \\
\hline China & $\mathrm{ns}$ & $\mathrm{p}<0.01 ;+\mathrm{ve}$ & $\mathrm{ns}$ \\
\hline Egypt & $\mathrm{ns}$ & $\mathrm{ns}$ & $\mathrm{p}<0.01 ;-\mathrm{ve}$ \\
\hline Haiti & $\mathrm{p}<0.01 ;+\mathrm{ve}$ & $\mathrm{p}<0.01 ;+\mathrm{ve}$ & $\mathrm{ns}$ \\
\hline India & $\mathrm{ns}$ & $\mathrm{ns}$ & $\mathrm{ns}$ \\
\hline Iran & $\mathrm{ns}$ & $\mathrm{p}<0.01 ;+\mathrm{ve}$ & $\mathrm{p}<0.01 ;-\mathrm{ve}$ \\
\hline Iraq & $\mathrm{p}<0.01 ;+\mathrm{ve}$ & $\mathrm{p}<0.01 ;+\mathrm{ve}$ & $\mathrm{p}<0.01 ;+\mathrm{ve}$ \\
\hline Madagascar & $\mathrm{p}<0.01 ;-\mathrm{ve}$ & $\mathrm{ns}$ & $\mathrm{p}<0.01 ;-\mathrm{ve}$ \\
\hline Mali & $\mathrm{p}<0.01 ;+\mathrm{ve}$ & $\mathrm{ns}$ & $\mathrm{ns}$ \\
\hline Mexico & $\mathrm{ns}$ & $\mathrm{p}<0.01 ;+\mathrm{ve}$ & $\mathrm{ns}$ \\
\hline Nigeria & $\mathrm{ns}$ & $\mathrm{ns}$ & $\mathrm{p}<0.01 ;+\mathrm{ve}$ \\
\hline Pakistan & $\mathrm{ns}$ & $\mathrm{p}<0.01 ;+\mathrm{ve}$ & $\mathrm{p}<0.01 ;+\mathrm{ve}$ \\
\hline Russia & $\mathrm{p}<0.01 ;-\mathrm{ve}$ & $\mathrm{p}=0.01 ;+\mathrm{ve}$ & $\mathrm{p}<0.01 ;-\mathrm{ve}$ \\
\hline South Africa & $\mathrm{p}=0.01 ;-\mathrm{ve}$ & $\mathrm{p}<0.01 ;+\mathrm{ve}$ & $\mathrm{p}<0.01 ;+\mathrm{ve}$ \\
\hline Turkey & $\mathrm{p}=0.01 ;+\mathrm{ve}$ & $\mathrm{ns}$ & $\mathrm{ns}$ \\
\hline Ukraine & $\mathrm{p}=0.02 ;+\mathrm{ve}$ & $\mathrm{p}<0.01 ;+\mathrm{ve}$ & $\mathrm{p}<0.01 ;-\mathrm{ve}$ \\
\hline Uzbekistan & $\mathrm{p}<0.01 ;-\mathrm{ve}$ & $\mathrm{p}<0.01 ;-\mathrm{ve}$ & $\mathrm{p}<0.01 ;-\mathrm{ve}$ \\
\hline Venezuela & $\mathrm{p}<0.01 ;+\mathrm{ve}$ & $\mathrm{p}<0.01 ;-\mathrm{ve}$ \\
\hline Yemen & $\mathrm{p}<0.01 ;+\mathrm{ve}$ & $\mathrm{v}$ & $\mathrm{v}$ \\
\hline
\end{tabular}

Note: S, O, and Yr refer to stability, openness, and year, respectively. -ve and +ve depict whether the significant regressions are negatively or positively correlated. 
Figures $4 \mathrm{a}$ and $4 \mathrm{~b}$ show the detailed chronology of changes in stability and openness for Iraq and Egypt. In the former case, both stability and openness are seen to improve overall despite a setback in stability during the early period. In the case of Egypt, there is an overall deterioration in both stability and openness over time, with a precipitous decline in stability during the latter period.

Figure 4a Chronology of stability vs openness for Iraq

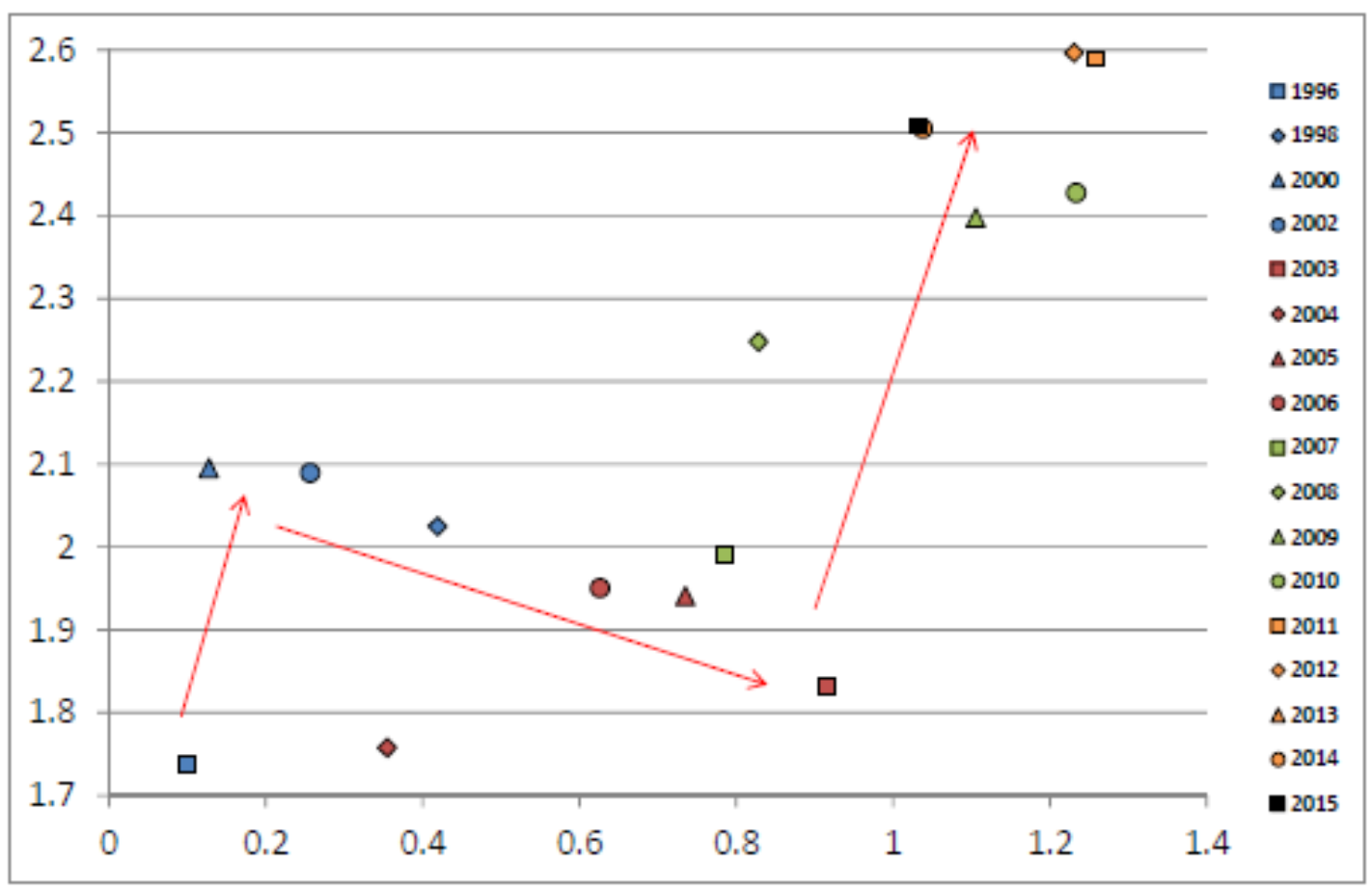

Figure 4b Chronology of stability vs openness for Egypt

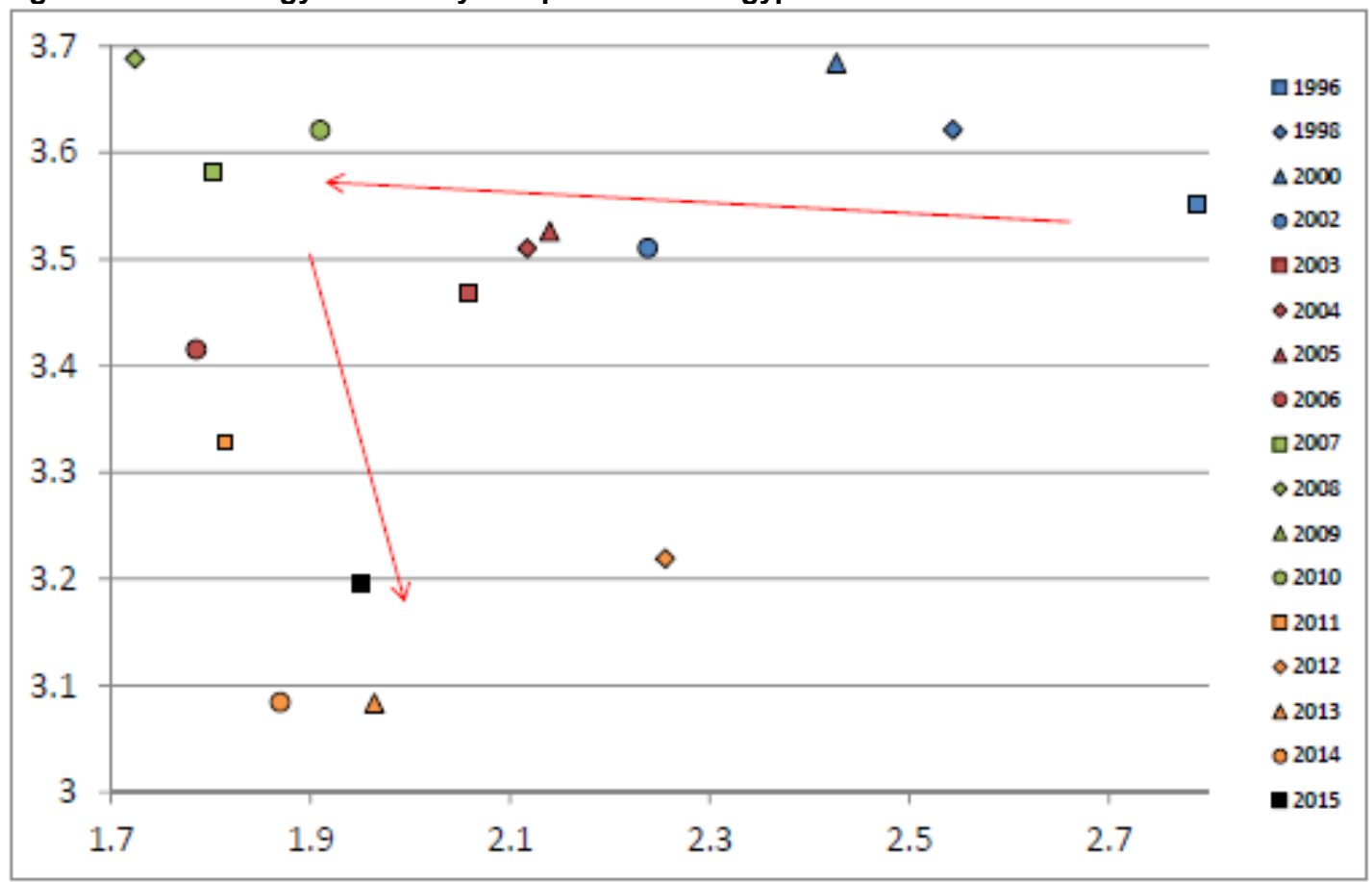


To test the volatility of state transitions, we determined the coefficient of variation (cv) of both the stability and openness for each state during the period from 1996 through 2015. Table 2 summarizes these values for each state type in increasing order of volatility. Accordingly, the least volatile states are the highly functional ones followed by moderately functional and struggling functional states. Next are the brittle and impoverished states that share a similar overall volatility followed by fragile states at more than twice the volatility.

Table 2. Coefficients of variation of stability (S) and openness (O) of state types between 1996 and 2015

\begin{tabular}{|l|l|l|l|}
\hline State Type & $\mathbf{S}$ & $\mathbf{O}$ & Average \\
\hline H (22) & 0.016 & 0.030 & 0.023 \\
\hline M (32) & 0.055 & 0.078 & 0.066 \\
\hline S (39) & 0.072 & 0.121 & 0.097 \\
\hline B (15) & 0.086 & 0.150 & 0.118 \\
\hline I (24) & 0.097 & 0.139 & 0.118 \\
\hline F (40) & 0.191 & 0.339 & 0.265 \\
\hline
\end{tabular}

Note: the numbers in parenthesis indicate the number of states of that type.

\section{$5 \quad$ Implications for Policy and Directions for Future Research}

The complexity and range of contexts surrounding hybrid regimes highlights the importance of examining how, and whether, members of the international community can contribute to strengthening stability and promoting democracy in countries that remain 'stuck' in the gray zone, identified through our analysis as states that occupy the lower portion of the J curve, as seen in Figure 1. For some, the capacity for donors to contribute to democratization and democratic consolidation is related to 'when' interventions are initiated in a transformation process. For instance, Takeuchi et al. (2011) suggests that in capacity trap countries, the inability for countries to provide security and services necessitates donor interventions designed to foster trust in public authority to enhance legitimacy, while in legitimacy trap countries, efforts to providing assistance to disadvantaged populations may enhance legitimacy.

Recognizing that countries in transition face a higher risk of conflict due to the institutional weakness of countries in transition (Mansfield and Snyder, 2002), Mansfield and Snyder (2007) suggest that donors should prioritize strengthening recipient institutions prior to providing broader democracy promotion and support. While such 'sequencing' is intended to maximize the likelihood of successful transitions by 'rationalizing' democratization through securing institutional strength prior to transformation, Carothers (2007) argues that a 'gradual' approach to building democracy, which encourages donors to contribute to support democratic principles and values in current contexts, could help develop democracy from current conditions rather than waiting for the conditions needed under sequencing.

Importantly, Grävingholt et al. (2012) note that while donors appear to acknowledge the need to sequence programming efforts, they do not rank or organize various, and potentially conflicting, objectives in a sequential manner. In some cases, this results in donors paying little attention to competing objectives, such as security issues in development assistance that donors face when engaging in democracy promotion (Grävingholt et al., 2012; Grimm and Leininger, 2012).

Grimm and Leininger (2012) note, particularly in post-conflict situations, that complex mandates are prone to competing objectives and mismanagement during implementation. In these cases, the risk is that donors will ignore competing objectives, using a 'wait and see' approach to identify challenges as they arise rather than seeking to integrate conflicting objectives into their strategies for democratization from the outset. While complex and multifaceted interventions are likely to 
be necessary in transitional regimes, Grimm and Leininger recommend that donors 'acknowledge the relevance of conflicting objectives and consider how intrinsic and extrinsic conflicts could develop as a part of their strategy building' (p. 408).

Moving beyond the question of how democratization programs are initiated, the capacity for development assistance to promote democratization has generated mixed results. For some (Tavares, 2003; Kalyvitis and Vlachaki, 2010; Kresting and Kilby, 2014), development assistance for democracy promotion is seen to have a positive effect on democratic development. Specifically, foreign aid is seen to decrease corruption (Tavares, 2003), increase the likelihood of observing partial or full democratization in recipients (Kalyvitis and Vlachaki, 2010), and provide an incentive for democratization through ex-ante and ex-post conditionality (Kresting and Kilby, 2014).

Alternatively, others show that aid can weaken governance quality in recipients by reducing the incentives for democratic accountability (Brautigam and Knack, 2004), and facilitating rent seeking behavior (Djanko, Montalvo and Reynal-Querol, 2008). In conducting a multivariate analysis of the impact of aid on democratization, Knack (2004) finds no evidence that aid contributed to democratization from 1975 to 2000 . Moreover, Wright (2009) suggests that the capacity of aid to contribute to democratization is linked to political leadership. While aid can provide an adequate incentive for democratization in cases where political leaders expect to remain in power following democratic transitions, Wright suggests that in other cases, aid can help dictators cling to power, discouraging transformation (e.g., *Ruling is about staying in power, not about good governance. * Bueno de Mesquita and Smith, 2012 (p 79)).

Examining the impact of aid on fragile states in particular, McGillivray and Feeny (2007) find important differences between the absorptive capacity and effectiveness of aid in fragile states versus other developing countries. For instance, McGillivray and Feeny find that while aid does contribute to development in fragile states, it appears to result in lower levels of growth than experienced by stable developing country recipients. Similarly, fragile states have a lower capacity to absorb aid resources than other countries. While McGillivray and Feeny suggest that many fragile states are under-aided relative to their absorptive capacity, many of the most fragile states receive more aid than they can absorb.

However, the question is not only whether donors can spark democratization through aid and other programming, but what types of programs are needed to enact change in partially liberalized regimes. As noted by Olcott and Ottoway (1999), partially liberalized regimes have already demonstrated a capacity to open political, economic, and social systems while retaining power, which could make them impervious to the incremental programming typically used to encourage democratic consolidation. In such countries, new approaches for encouraging further liberalization and promoting democratic reform are needed.

We now turn our attention to intervention policy regarding the imminence of violent conflict. Several agencies, institutions, and think tanks regularly publish forecasts of conflict risk around the world (e.g., International Crisis Group has issued monthly assessments under CrisisWatch since 2003). Recently, the European Commission's Joint Research Centre (JRC) released the Global Conflict Risk Index (GCRI) for the prediction of conflict within a state. In their report (Smidt et al., 2016), they listed twenty states with the highest predicted risk of violent conflict, which included Mexico and India. While informative, perhaps more critical for intervention decision policy is how damaging an outbreak of conflict might be. Arguably, Mexico and India could probably survive violent conflict without crippling effect given their relatively strong capacity, whereas fragile states such as Afghanistan, Central African Republic, Democratic Republic of Congo, Ethiopia, Iraq, Sudan, and Yemen, which are also on the top 20 list, would likely suffer further severe destabilization. The other states on the list might fare somewhat better given their 
modestly higher capacity (see Figure 1 for the identity and placement of these states with respect to their stability, which comprises capacity). Hence, greater attention for intervention might be warranted for the weaker states with low capacity to deal with internal conflict.

These insights provide the motivation for the development of a derivative index, which we identify as the Global Conflict Damage Index (GCDI). The CGDI can be applied in concert with conflict risk as a decision support tool for intervention policy. As a simple demonstration, assume the GCDI equals the GCRI score divided by the value of Stability for 2015. The Central African Republic and Afghanistan top the list for both GCRI and GCDI, followed by Ukraine and Nigeria having the next highest GCRI scores while Yemen and the Democratic Republic of Congo have the next highest GCDI scores (see Figure 5). Although Ukraine and Nigeria might be at greater risk of conflict, Yemen and the Democratic Republic of Congo might warrant greater attention due to a higher potential of destabilizing conflict damage. Figure 5 also shows that India and Mexico have the lowest GCDI although their GCRI scores are comparable to several other states with a higher potential of destabilizing conflict damage.

Figure 5: Comparison of GCRI and GCDI scores for 15 of the top 20 predicted states at risk of violent internal conflict.

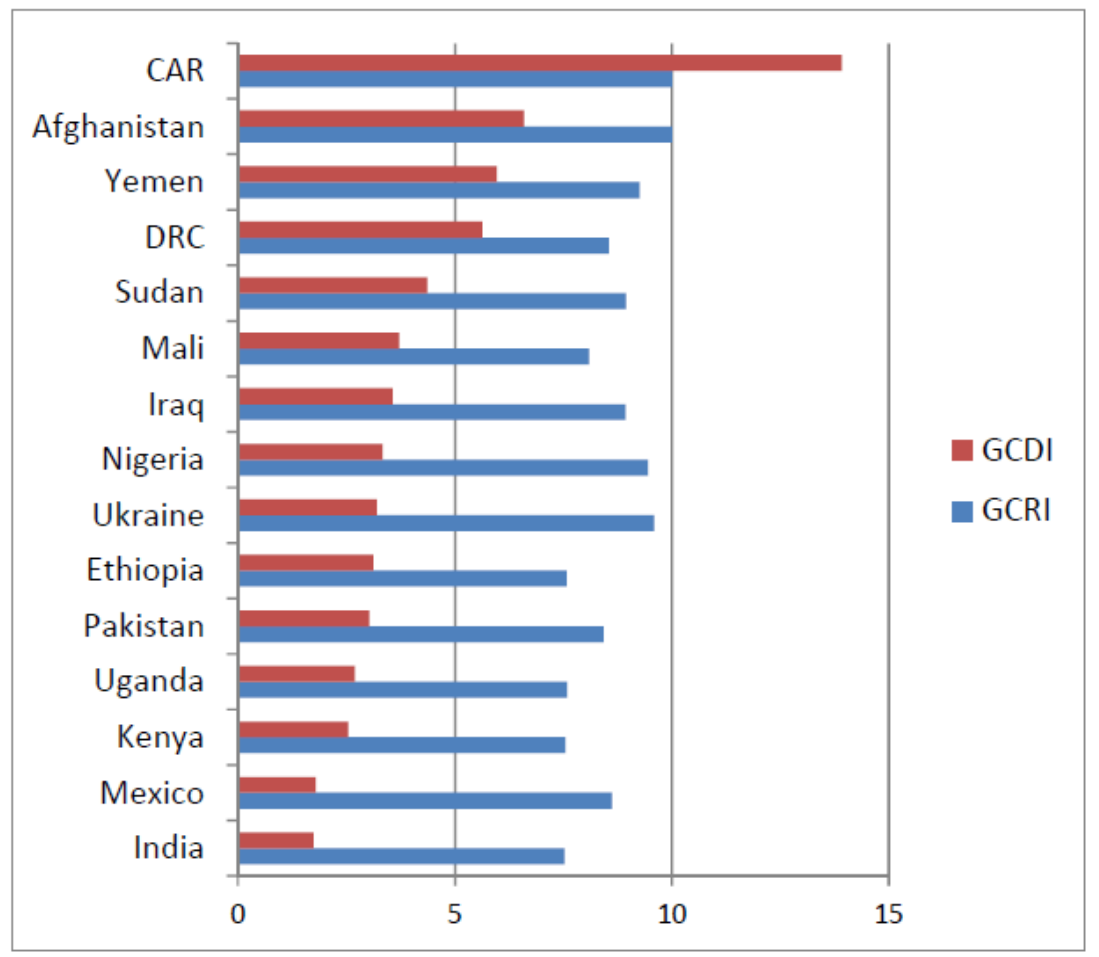

\section{$6 \quad$ Conclusions}

We believe that policies for preventing backsliding and reversals require a more robust analytical framework with which to identify country changes over time and more importantly greater specificity on the interrelated dimensions of capacity, authority, and legitimacy. Our state typology provides that level of specificity in comparison to single rank indexes (Tikuisis and Carment 2017). Such an approach not only identifies the direction of state change but also its significance. This is an important addition to indexes that typically only identify relative rankings. In brief, our typology provides additional insights regarding state instability and the possibility of improved policy application. 
More specifically, understanding the relationship between capacity and legitimacy leading to (in)stability is relevant for clarifying the types of interventions that donors could initiate to improve state-building under various conditions. Using the state dimensions of authority, capacity, and legitimacy, we constructed a relatively simple formulation of stability vs openness that generated a fattened J curve with enhanced explanatory power. This enhancement was possible through the categorization of states using the above three dimensions of state performance that clearly separated well performing states from hybrid regimes susceptible to various degrees of instability near and below the turnover of the J curve. The most susceptible states exhibit the highest volatility shifts in both stability and openness, and therefore are the most in need of effective intervention policy. Future work will focus on the development of the GCDI. 


\section{References}

Acemoglu, D., and Robinson, J. 2001. A Theory of Political Transitions. American Economic Review, 91(4): 938-963.

Acemoglu, D., Johnson, S., and Robinson, J. 2001. The Colonial Origins of Comparative Development: An Empirical Investigation. American Economic Review, 91(5): 1369_ 1401.

Bäck, H., and Hadenius, A. 2008. Democracy and State Capacity: Exploring a J-Shaped Relationship. Governance: An International Journal of Policy, Administration, and Institutions, 21(1): 1-24.

Baliamoune-Lutz, M. N., and McGillivray, M. 2008. State Fragility: Concept and Measurement. Research Paper 2008/44. Helsinki, UNU-WIDER.

Bermeo, N. 2016. On Democratic Backsliding. Journal of Democracy, 27(1): 5-19.

Boix, C., and Stokes, S.C. 2003. Endogenous Democratization. World Politics, 55(4): 517-549.

Bratton, M. 2007. Institutionalizing Democracy in Africa: Formal or Informal? Journal of Democracy, 18(3): 96-110.

Brinkerhoff, D. 2007. Capacity Development in Fragile States. European Centre for Development Policy Management Discussion Paper No. 58D. Maastricht, European Centre for Development Policy. Available at: http://ecdpm.org/wp-content/uploads/2013/11/DP58D-Capacity-Development-in-Fragile-States-2007.pdf

Brautigam, D., and Knack, S. 2004. Foreign Aid, Institutions and Governance in Sub-Saharan Africa. Economic Development and Cultural Change, 52(2): 255-85.

Brumberg, D. 2005. Liberalization Versus Democracy. In Uncharted Journey: Promoting Democracy in the Middle East, ed. Carothers, T. and Ottaway, M. Washington D.C: Carnegie Endowment for International Peace.

Bremmer, I. 2006. The J Curve: A New Way to Understand Why Nations Rise and Fall. New York: Simon \& Schuster, Inc.

Bueno de Mesquita, B., Smith, A., Siverson, R. A., and Morrow, J. D. 2003. The Logic of Political Survival. MIT Press: Cambridge, MA.

Bueno de Mesquita, B., and Smith, A. 2012. The Dictator's Handbook: Why Bad Behavior is Almost Always Good Politics. New York: Perseus Books.

Call, C. T. 2011. Beyond the 'Failed State': Towards Conceptual Alternatives. European Journal of International Relations, 17(2): 303-326.

Carment, D., El-Achkar, S., Prest, S., and Samy, Y. 2006. The 2006 Country Indicators for Foreign Policy: Opportunities and Challenges for Canada. Canadian Foreign Policy Journal, 13(1): 1-35.

Carment, D., Prest, S., and Samy, Y. 2010. Security, Development, and the Fragile State: Bridging the Gap Between Theory and Policy. London: Routledge.

Carothers, T. 2002. The End of the Transition Paradigm. Journal of Democracy, 13(1): 5-21.

Carothers, T. 2007. The 'Sequencing' Fallacy. Journal of Democracy, 18(1): 12-27.

Collier, P., Elliot, L., Hagre, H., Hoeffler, A., Reynal-Querol, M., and Sambanis, N. 2003. Breaking the Conflict Trap: Civil War and Development Policy. Washington D.C.: World Bank.

Debiel, T., Glassner, R., Schetter, C., and Terlinden, U. 2009. Local State-Building in Afghanistan and Somaliland. Peace Review: A Journal of Social Justice, 21: 38-44.

Diamond, L. 1994. Towards Democratic Consolidation. Journal of Democracy, 5(3): 4-17.

Diamond, L. 1999. Developing Democracy: Toward Consolidation. Baltimore: Johns Hopkins University Press.

Diamond, L. 2002. Thinking about Hybrid Regimes. Journal of Democracy, 13(2): 25-31.

Diamond, L. 2015. Facing Up to the Democratic Recession. Journal of Democracy, 26(1): 141155. 
Diamond, L., Linz, J. J., and Lipset, S. M. (Eds). 1989. Democracy in Developing Countries: Latin America. Boulder: Lynne Rienner.

Djankov, S., Montalvo, J. G., and Reynal-Querol, M. 2008. The Curse of Aid. Journal of Economic Growth, 13(3): 169-194.

Doorenspleet, R. 2005. Democratic Transitions: Exploring the Structural Sources of the Fourth Wave. Boulder: Lynne Rienner.

Freedom House. 2016. Freedom in the World 2016. Washington D.C.: Freedom House.

Goldstone, J. A. 2008. Pathways to State Failure. Conflict Management and Peace Science, 25(4): 285-296.

Goldstone, J. A., and Ulfelder, J. 2004. How to Construct Stable Democracies. The Washington Quarterly, 28(1): 9-20.

Grävingholt, J., Leininger, J., and von Haldenwang, C. 2012. Evaluation Study: Effective Statebuilding? Copenhagen: DANIDA.

Grimm, S., and Leininger, J. 2012. Not All Good Things Go Together: Conflicting Objectives in Democracy Promotion. Democratization, 19(3): 391-414.

Hegre, H., Ellingsen, T., Gates, S., and Gleditsch, N. P. 2001. Toward a Democratic Civil Peace? Democracy, Political Change, and Civil War, 1816-1992. American Political Science Review 95(1): 33-48.

Hirschmann, A. O. 1986. Rival Views of Market Society and Other Recent Essays. New York: Viking Penguin.

Horowitz, D. L. 1985. Ethnic Groups in Conflict. Berkeley: University of California Press.

Horowitz, D. L. 1993. Democracy in Divided Societies. Journal of Democracy, 4(4): 18-38.

Houle, C. 2009. Inequality and Democracy: Why Inequality Harms Consolidation but Does Not Affect Democratization. World Politics 61(4): 589-622.

Huber, E., Rueschemeyer, D., and Stephens, J. D. 1993. The Impact of Economic Development on Democracy. Journal of Economic Perspectives, 7(3): 71-86.

Huntington, S. P. 1993. The Third Wave: Democratization in the Late Twentieth Century. Oklahama: Oklahoma University Press.

Kalyvitis, S., and Vlachaki, I. 2010. Democratic Aid and The Democratization of Recipients. Contemporary Economic Policy, 28(2): 188-218.

Kapstein, E. B., and Converse, N. 2008. The Fate of Young Democracies. Cambridge: Cambridge University Press.

Klem, B. 2004. A Commentary on the World Bank Report 'Breaking the Conflict Trap'. Clingendael Working Paper 25. Available at: http://www.clingendael.nl/sites/default/files/20040100 cru working paper 25.pdf

Knack, S. 2004. Does Foreign Aid Promote Democracy? International Studies Quarterly, 48(1): 251-266.

Knutsen, C. H., and Nygård, H. M. 2015. Institutional Characteristics and Regime Survival: Why Are Semi-democracies Less Durable than Autocracies and Democracies? American Journal of Political Science, 59(3): 656-670.

Kresting, E., and Kilby, C. 2014. Aid and Democracy Redux. European Economic Review, 67: $125-143$.

Leftwich, A. 2010. Beyond Institutions: Rethinking the Role of Leaders, Elites and Coalitions in the Institutional Formation of Developmental States and Strategies. Forum for Development Studies, 37(1): 93-111.

Leftwich, A., and Wheeler, C. 2011. Politics, Leadership and Coalitions in Development. DLP Research and Policy Workshop Report. Available at: 
http://publications.dlprog.org/Politics, $\% 20$ Leadership $\% 20$ and $\% 20$ Coalitions $\% 20$ in $\% 20$ Development $\% 20-\% 20$ Findings, $\% 20$ insights $\% 20$ and $\% 20$ guidance.pdf

Levitsky, S., and Murillo, M. V. 2009. Variation in Institutional Strength. Annual Review of Political Science 12: 115-133.

Levitsky, S., and Way, L. A. 2002. The Rise of Competitive Authoritarianism. Journal of Democracy, 13(2): 51-65.

Lipset, S. M. 1959. Some Social Requisites of Democracy: Economic Development and Political Legitimacy. American Political Science Review, 53(1): 69-105.

Lust, E., and Waldner, D. 2015. Unwelcome Change: Understanding, Evaluating, and Extending Theories of Democratic Backsliding. Washington D.C.: USAID. Available at: http://pdf.usaid.gov/pdf docs/PBAAD635.pdf

Mainwaring, S. 1989. Transitions to Democracy and Democratic Consolidation: Theoretical and

Comparative Issues. Kellogg Institute Working Paper \#130. Available at: https://kellogg.nd.edu/publications/workingpapers/WPS/130.pdf

Mansfield, E., and Snyder, J. 2002. Democratic Transitions, Institutional Strength and War. International Organizations, 56(2): 297-337.

Mansfield, E., and Snyder, J. 2007. The 'Sequencing' Fallacy. Journal of Democracy, 18(3): 5-9.

Marshall, M. G., and Cole, B. R. 2014. Global Report 2014: Conflict, Governance, and State Fragility. Vienna, VA: Center for Systemic Peace.

McGillivray, M., and Feeny, S. 2008. Aid and Growth in Fragile States. Research Paper 2008/3. Helsinki: UNU-WIDER

Means, G. P. 1996. Soft Authoritarianism in Malaysia and Singapore. Journal of Democracy, 7(4): 103-117.

Menocal, A. R., and Fritz, V. and Rakner, L. 2008. Hybrid Regimes and the Challenges of Deepening and Sustaining Democracy in Developing Countries. South African Journal of International Affairs, 15(1): 29-40.

Migdal, J. 1988. Strong Societies and Weak States: State-Society Relations and State Capabilities in the Third World. Princeton University Press.

Migdal, J. 2001. State in Society: Studying how States and Societies Transform and Constitute One Another. Cambridge: Cambridge University Press.

North, D. 1990. Institutions, Institutional Change and Economic Performance. Cambridge: Cambridge University Press.

North, D. 1995. The New Institutional Economics and Third World Development. In The New Institutional Economics and Third World Development, ed. J. Harriss, J. Hunter and C. M. Lewis. London: Routledge.

North, D. 2005. Understanding the Process of Economic Change. Princeton, NJ: Princeton University Press.

North, D., Wallis, J. J., Webb, S. B., and Weingast, B. R. 2007. Limited Access Orders in the Developing World: A New Approach to the Problems of Development. World Bank Policy Research Working Paper 4359. http://econweb.umd.edu/ wallis/MyPapers/ Limted Access Orders in the Developing WorldWPS4359.pdf

O’Donnell, G., and Schmitter, P. C. 1986. Transitions for Authoritarian Rule: Comparative Perspectives. Baltimore: Johns Hopkins University Press.

Olson, M. 1993. Dictatorship, Democracy, and Development. American Political Science Review, 87(3): 567-576

Olcott, M. B., and Ottaway, M. 1999. Challenge of Semi-Authoritarian. Carnegie Paper No 7. Washington: D.C: Carnegie Institute.

Ottaway, M. The Rise of Semi-Authoritarianism. Washington, D.C: Carnegie Endowment for International Peace.

Pop-Eleches, G., Robertson, G. B. 2015. Structural Conditions and Democratization. Journal of Democracy, 26(3): 144-156. 
Przeworkski, A., Alvarez, M., Cheibub, A., and Limongi, F. 2000. Democracy and Development. Cambridge: Cambridge University Press.

Przeworski, A., and Limongi, F. 1997. Modernization: Theories and Facts. World Politics, 49(2): 155-183.

Przeworski, A., Alvarez, M., Cheibub, A., and Limongi, F. 1996. What Makes Democracies Endure? Journal of Democracy, 7(1): 39-53.

Rotberg, R. 2012. Transformative Political Leadership: Making a Difference in the Developing World. Chicago: University of Chicago Press.

Sachs, J. 2005. The End of Poverty. New York: Penguin Books.

Schedler, A. 1998. What is Democratic Consolidation? Journal of Democracy, 9(2): 91-107.

Schedler, A. 2006. Electoral Authoritarianism: The Dynamics of Unfree Competition. Boulder: Lynne Rienner.

Smidt, M., Vernaccini, L., Hachemer, P., and De Groeve, T. 2016. The Global Conflict Risk Index (GCRI): Manual for Data Management and Product Output. Version 5, European Commission Joint Research Centre Technical Report, EUR 27908 EN. Available from http://conflictrisk.jrc.ec.europa.eu/Downloads/report v2.2.pdf

Stewart, F., and Brown, G. 2009. Fragile States. CRISE Working Paper No. 51. Oxford: CRISE.

Strand, H., Hegre, H., Gates, S., and Dahl, M. 2012. Democratic Waves? Global Patterns of Democratization. Paper for International Conference on Democracy, Oslo 2012.

Svolik, M. 2008. Authoritarian Reversals and Democratic Consolidation. American Political Science Review, 102(2): 153-168.

Takeuchi, S., Murotani, R., and Tsunekawa, K. 2011. Capacity Traps and Legitimacy Traps: Development Assistance and State Building in Fragile Situations. In Catalyzing Development: A New Vision for Aid, ed. H. Kharas, K. Makino and W. Jung. Washington D.C: Brookings Institute Press.

Tavares, J. 2003. Does Foreign Aid Corrupt? Economic Letters, 79: 99-106.

Tikuisis, P., Carment, D., Samy, Y., and Landry, J. 2015. Typology of State Types: Persistence and Transition. International Interactions, 41(3): 565-582.

Tikuisis, P., and Carment, D. 2017. Categorization of States Beyond Strong and Weak. Stability: International Journal of Security and Development.

Vanhanen, T. 2000. A New Dataset for Measuring Democracy, 1810-1998. Journal of Peace Research, 37(2): 251-265.

Volker B., Brown, M. A., and Clements, K. P. 2009. Hybrid Political Orders, Not Fragile States. Peace Review: A Journal of Social Justice, 21(1): 13-21.

Wigell, M. 2008. Mapping 'Hybrid Regimes': Regime Types and Concepts in Comparative Politics. Democratization, 15(2): 230-250.

Wright, J. 2009. How Foreign Aid Can Foster Democratization in Authoritarian Regimes. American Journal of Political Science, 53(3): 552-571.

Zakaria, F. 1997. The Rise of Illiberal Democracy. Foreign Affairs, 76(6): 22-43. 